\title{
IMMUNOSUPRESSANT EFFECT OF THE EXTRACT OF Tridax procumbens ON LYMPHOCYTE CELLS LINE FROM PATIENTS WITH SYSTEMIC LUPUS ERYTHEMATOUS: IMMUNOGLOBULIN GBIOMARKER
}

\author{
Abdul Khairul Rizki Purba ${ }^{1}$, Endang Mahati ${ }^{2}$,Yolanda Dyah Kartika ${ }^{3}$, Indwiani Astuti ${ }^{3}$, Nyoman Kertia ${ }^{4}$ \\ ${ }^{1}$ Department of Pharmacology, Faculty of Medicine, University of Airlangga \\ ${ }^{2}$ Department of Pharmacology, Faculty of Medicine, University of Diponegoro \\ ${ }^{3}$ Department of Pharmacology, Faculty of Medicine, University of Gadjah Mada \\ ${ }^{4}$ Department of Internal Medicine, Hospital of Sardjito, Yogyakarta
}

\begin{abstract}
Systemic Lupus Erythematous (SLE) is one of the major autoimmune diseases that can cause severe damage to the tissues and organs in the body and lead to high mortality rates. The clinical manifestations are characterized by the production of autoantibody immunoglobulin $G(I g G)$ that fights component of the nucleus. The present scientific information issues about peculiar property of Tridax procumbens as immunosuppressant by inhibiting enzyme of cyclooxygenase-2 (COX-2) on surface of B cells. This study approved effect of the extract of Tridax procumbens on human lymphocytes cells line with SLE disease. The aim of this study was to approve effect of extract of Tridax procumbens in suppressing Ig $G$ concentration from patient with stable SLE and patient with active SLE in vitro. This study was an in vitro experimental design on lymphocytes cell line that was isolated from whole blood patient with stable SLE and active SLE. Lymphocyte cells from healthy volunteer were also collected as control. American Rheumatism Association Diagnostic was used for inclusion criteria.Tridax procumbens was extracted with maceration method in solution of ethyl acetate. The extract was divided in several doses as immunosuppressant i.e.1000; 250; 62.5; 31.25; 15.13; and $3.91 \mu \mathrm{g} / \mathrm{mL}$. Supernatant of the cultured cells was collected and examined for measuring Ig $G$ concentration as secretion from activated B cells by ELISA. Ethical clearance had been completed before this study started. The extract of Tridax procumbens significantly suppressed Ig $G$ secretion in patient with stable SLE at dose over $62.5 \mu \mathrm{g} / \mathrm{mL}$, but Ig $G$ concentration in patient with active SLE was significantly increased when compared with control. Furthermore from the analysis, effect of the Tridax procumbens extract on Ig $G$ concentration followed dose dependent response. In in-vitro study, the extract of Tridax procumbens could significantly suppress Ig $G$ secretion in healthy volunteer and patient with stable SLE. Otherwise, the extract does not suggest for patient with active SLE and it needs caution in use and investigation in-depth.
\end{abstract}

Keywords: SLE, Tridax procumbens, immunoglobulin $G$

\begin{abstract}
ABSTRAK
Penyakit Systemic Lupus Erythematous (SLE) merupakan salah satu penyakit autoimun yang sering menyebabkan kerusakan jaringan dan organ sehingga angka kematiannya tinggi. Karakteristik patognomonik penyakit SLE ditandai ada produksi auto antibody immunoglobulin $\mathrm{G}$ (Ig G) yang melawan komponen nukleosom tubuh sendiri. Penelitian ilmiah terbaru menunjukkan bahwa ekstrak Tridax procumbens memiliki efek imunosupresan
\end{abstract}


melalui hambatan enzim cyclooxygenase-2 (COX-2) pada permukaan sel B. Pada studi ini menguji efek ekstrak Tridax procumbens pada cells line limfosit dari pasien SLE. Tujuan penelitian ini adalah mengetahui efek ekstrak Tridax procumbens dalam menekan konsentrasi Ig $G$ pasien dengan SLE stabil dan pasien dengan SLE aktif secara in vitro. Penelitian ini merupakan penelitian eksperimen pada cell line limfosit yang diisolasi dari whole blood pasien dengan SLE stabil dan SLE aktif. Kelompok kontrol limfosit diambil dari sukarelawan sehat. Kriteria inklusi pasien yang mengikuti penelitian ini berdasarkan kriteria diagnostik American Rheumatism Association. Tridax procumbens diekstraksi dengan metode maserasi larutan etil asetat. Ekstrak dibagi menjadi beberapa dosis sebagai imunosupresan yaitu 1000; 250; 62,5; 31,$25 ; 15,13$; dan 3,91 $\mu \mathrm{g} / \mathrm{mL}$. Supernatan dari sel kultur dikoleksi dan diukur konsentrasi Ig $\mathrm{G}$ yang merupakan sekresi sel $\mathrm{B}$ dengan menggunakan metode ELISA. Persetujuan etik dilakukan sebelum penelitian dilakukan. Ekstrak Tridax procumbens menekan sekresi Ig G pasien dengan SLE stabil pada dosis diatas 62,5 $\mu \mathrm{g} / \mathrm{mL}$, namun konsentrasi Ig G dari pasien dengan SLE aktif meningkat secara signifikan dibandingkan dengan kontrol. Efek ekstrak Tridax procumbens pada konsentrasi Ig G mengikuti dose dependent response. Pada penelitian ini, ekstrak Tridax procumbens dapat menekan sekresi Ig G dari pasien dengan SLE stabil dan sukarelawan sehat. Pemberian ekstrak Tridax procumbens tidak dianjurkan pada pasien dengan SLE aktif, namun hal ini masih membutuhkan penelitian lebih mendalam.

Keywords: SLE, Tridax procumbens, imunoglobulin G

\section{INTRODUCTION}

Systemic lupus is disease involving multi system disorder in women and men at a young age (1). It is a complex disease that has characteristics such hyperactivity of immune system and built up damage to the blood vessels (2). Consequently, the manifestation is in many organs throughout the body (3). The actual incidence of the disease system iclupusis very difficult to estimate, because of the complexity of the disease and the difficulty of diagnosis. In the United State, a developed country occurred more than 16,000 new cases a year. According to the survey, more people suffered from lupus than AIDS, cerebral palsy, and multiple sclerosis (4).

The main cause of this disease has still unknown certainly. The incidence of this disease showed that case of SLE reached $25-50 \%$ in identical twins and $5 \%$ in dizygotic twins. This suggested that genetic factors had played an important role as a factor in disease predisposition. However, almost all cases were sporadic and a rise non genetic that could be identified, so environmental factors were also known to have an essential role in the onset of the disease (5). The pathognomonic sign of lupus is found of auto antibodies that formed to fight the nuclear component. Auto antibodies are directly involved in the activation of complement and immune complex formation. Thus, this inflammatory response affects in many tissues and more common such the skin and kidneys (6).

Tridax procumbens, in Indonesia, known herbs Songgolangit, widely used as ingredients (7). In traditional medicine, the leaves of this plant were used all parts of the plant to treat some infections such bronchitis and diarrhea (8). Pharmacological studies indicated that the herb had anti-inflammatory effects, hepatoprotector, anti-leishmania, antihyperglycemic, and hair grower. From the research phytochemicals, the herbs were isolated constituents of lipids, sterols, 
flavonoids, polysaccharides and derivate bergenin. The leaf juice of Tridax procumbens has affect for healing open wounds due to greater anti-inflammatory effect (9). Tridax procumbens resembled steroid effect on minimizing wound contraction and granulation (10). Antiinflammatory effects of Tridax procumbens obtained through inhibition of cyclooxygenase-2 (COX-2) enzyme (6). This enzyme had important component in class switching of $\mathrm{Ig} G$ on surface of lymphocytes B. By inhibiting of this pathway, it leaded to suppress autoantibody Ig G concentration (11). The recent study has also developed monoclonal antibody that has target at B cells (12).

This study was expected to explore Tridax procumbens that had immunosuppressant effects by inhibition of COX-2 enzyme in the cell surface of $\mathrm{B}$ lymphocytes. As a result, secretion of immunoglobulin $\mathrm{G}$ was suppressed directly as an essential role in management therapy in SLE disease.

\section{METHODS}

This study is an experimental research laboratory with ethical clearance in humans. The research analyzed Tridax procumbens extract on cultured lymphocytes. In this study, lymphocytes were taken from whole blood two lupus patients; one was from patient with stable lupus, another was sample from patient with exacerbated lupus. Normal lymphocyte cells were taken from whole blood a healthy volunteer as control. Patients diagnosed with SLE based on ARA criteria by physician at department of internal medicine, Hospital of Sardjito, Yogyakarta. In addition, inclusion criteria included female with age of 20 to 50 years old, and not being consumption any immunomodulatory agents for 7 days prior blood sample taken. Patient with concomitants disease and being either pregnant or breast feeding was excluded in this study.

Tridax procumbens was extracted with maceration method in solution of ethyl acetate. Concentrations of the extract were $1000 ; 250 ; 62.5 ; 15.125$, and $3.91 \mu \mathrm{g} / \mathrm{mL}$. As positive control, prednisone was used for standard treatment in SLE as immunosuppressant and aspirin was used for COX-2 enzyme inhibitor. Either prednisone or aspirin was prepared in concentration of $250 ; 62.5 ; 15.125$, and $3.91 \mu \mathrm{g} / \mathrm{mL}$. All of concentrations were replicated in triplet.

Lymphocytes were isolated from whole blood samples of lupus patients as treatmet cells and a healthy volunteer as control cells. Whole blood was washed with $10 \%$ PBS twice and centrifuged by $1600 \mathrm{rpm}$ for 10 minutes. Supernatant was discarded before the bottom layer was put with Isopaque-ficoll in density of 0.074 approximately $6 \mathrm{~mL}$ in tubes. Then the whole blood is put through the wall of the tube carefully. Furthermore, it was centrifuged at speed of $1600 \mathrm{rpm}$ for 10 minutes. Finally, buffycoat isolated and washed with PBS (13).

Lymphocyte cells were growth in RPMI 1640 , cell cultured media, with $10 \%$ FBS for 3 days in 96 wells in 3 groups, one group was lymphocytes from patient with stable lupus, one group was lymphocytes from patient with exacerbated or active lupus, and another was from healthy volunteer. Each group had 6 wells for the extract, 5 wells for prednisone treatment, and 5 wells for aspirin treatment. All of concentrations were replicated in triplet. Supernatant was taken to measure the concentration of Ig $\mathrm{G}$ by using the humanimmunoglobulin $\mathrm{G}$ ELISA procedures (11). 
Analysis is based on comparison between the concentration of immunoglobulin $\mathrm{G}$ in the extract and in control group. The average concentration of $\mathrm{Ig} G$ within the extract group was compared statistically to prednisone and aspirin group. The results of the analysis revealed significant based on the value of statistical significance $(p)$ by using a statistical test. Differences were considered significant if $p$-value was less than 0.05 .

\section{RESULTS AND DISCUSSIONS}

Tridax procumbens was isolated from Health Office UPT Materia Medica, Malang, East Java. Tridax procumbens was extracted with maceration method since the materials were unstable in heated environment. The extraction process used semi-polar solvent of ethyl acetate, thus it was also expected to extract components of polar primarily inside endosel.

\section{Effect of Tridax procumbens on Ig G concentration}

The results of the calculation $\mathrm{Ig} G$ concentration in supernatants of culture of lymphocytes that had been given the extract of ethyl acetate extract for 3 days can be seen in Table1. Untreated group as negative control was performed on cultured lymphocytes within each test group (the healthy, stable SLE and active SLE patients). Basically, start level of Ig G concentrations each group were difference, the highest level was from cultured lymphocytes of patient with active SLE. There was a significant decrease in the levels of immunoglobulin $G$ in cultured lymphocytes of either healthy volunteer or patient with stable SLE in the concentration of the extract above 62.5 $\mu \mathrm{g} / \mathrm{mL}$. On the other hand, the opposite occurred in patient with active SLE, the concentration of immunoglobulin $\mathrm{G}$ increased significantly from the lowest dose to the highest dose of the extract. This suggested that the ethyl acetate extract of Tridax procumbens not recommended for people with SLE who has experienced an attack of lupus but this needs further study.

In this study, positive control was given the immunosuppressant prednisone as the treatment of SLE. The concentration of the test immunosuppressant prednisone only mphocyte cell lines was $250 ; 62.5 ; 15.125$, and $3.91 \mu \mathrm{g} / \mathrm{mL}$. The results of the calculation of the concentration of Ig $\mathrm{G}$ in supernatants of lymphocytes cultured cells that have been given prednisone for 3 days can be seen in Table 2. Prednisone, acortico steroid drug, had a mechanism by inhibiting the expression of the role of phospholipase A on the cell membrane that could lead to suppression of excretion of Ig G (11)(14). In the statistical results indicated there was a decrease in the concentration of Ig $\mathrm{G}$ from healthy volunteer, patients with stable SLE, and in patients with active SLE. Overall, in Table 2 also showed that the decrease in the concentration of Ig G occurred in lowest to highest concentration of prednisone.

The use of aspirin for this study as a positive control based on previous studies related to that the ethyl acetate extract of Tridax procumbens had effect on suppression of Ig G secretion by inhibition of COX pathway (11).

The concentration of aspirin only mphocytes cultured cells was $250 ; 62.5$; 15.125 , and $3.90625 \mu \mathrm{g} / \mathrm{mL}$. The results of the calculation of the concentration of immunoglobulin $G$ in supernatants of lymphocytes cultured cells that have been given aspirin for 3 days can be seen in table 2. 
Immunosupressant Effect of the Extract of Tridax Procumbens on Lymphocyte Cells Line from Patients with Systemic Lupus Erythematous: Immunoglobulin Gbiomarker

Tabel 1. Concentrations of Ig $\mathrm{G}$ in cultured lymphocytes that had given extract of Tridax procumbens.

\begin{tabular}{llll}
\hline $\begin{array}{l}\text { Types of cultured } \\
\text { lymphocytes }\end{array}$ & $\begin{array}{l}\text { Concentration the } \\
\text { extract }(\mu \mathrm{g} / \mathrm{mL})\end{array}$ & $\begin{array}{l}\text { Concentration of Ig G }(\mathrm{ng} / \mathrm{mL}) \\
(\text { mean } \pm \text { SD) }\end{array}$ & p value \\
\hline Healthy volunteer & 1000 & $660.38 \pm 4.50$ & 0.001 \\
& 250 & $696.38 \pm 27.47$ & 0.014 \\
& 62.50 & $701.17 \pm 4.78$ & 0.023 \\
& 15.13 & $714.32 \pm 0.00$ & 0.106 \\
& 3.91 & $721.00 \pm 4.57$ & 0.231 \\
Patient with stable & 0 & $736.56 \pm 0.36$ & - \\
SLE & 1000 & $632.99 \pm 0.93$ & $<0.001$ \\
& 250 & $634.82 \pm 27.82$ & $<0.001$ \\
& 62.50 & $696.42 \pm 29.50$ & 0.001 \\
Patient with active & 15.13 & $785.72 \pm 11.86$ & 0.132 \\
SLE & 3.91 & $808.64 \pm 8.67$ & 0.685 \\
& 0 & $816.18 \pm 4.37$ & - \\
& 250 & $1113.14 \pm 6.51$ & $<0.001$ \\
& 15.50 & $928.69 \pm 0.91$ & $<0.001$ \\
& 3.91 & $926.14 \pm 0.90$ & 0.001 \\
& 0 & $910.01 \pm 1.33$ & 0.001 \\
\hline
\end{tabular}

$\mathrm{p}$ value was adjusted based on baseline level the concentration of Ig G without treatment

Tabel 2. Concentrations of Ig G in cultured lymphocytes had been given the extract of Tridax procumbens, prednison and aspirin

\begin{tabular}{|c|c|c|c|c|c|c|}
\hline \multirow{2}{*}{$\begin{array}{l}\text { Types of cultured } \\
\text { lymphocytes }\end{array}$} & \multirow{2}{*}{$\begin{array}{l}\text { Dose } \\
(\mu \mathrm{g} / \mathrm{mL})\end{array}$} & \multicolumn{2}{|c|}{$\operatorname{Ig~G~(ng/mL)~}$} & \multirow{2}{*}{$\begin{array}{l}\mathrm{p} \\
\text { value }\end{array}$} & \multirow{2}{*}{$\begin{array}{l}\text { Ig G }(\mathrm{ng} / \mathrm{mL}) \\
\text { Aspirin } \\
(\text { mean } \pm \mathrm{SD})\end{array}$} & \multirow{2}{*}{$\begin{array}{l}\mathrm{p} \\
\text { value }\end{array}$} \\
\hline & & $\begin{array}{l}\text { The extract } \\
(\text { mean } \pm \text { SD) }\end{array}$ & $\begin{array}{l}\text { Prednison } \\
(\text { mean } \pm \text { SD })\end{array}$ & & & \\
\hline \multirow[t]{4}{*}{ Healthy volunteer } & 250 & $696.38 \pm 27.47$ & $613.47 \pm 5.38$ & & $614.94 \pm 2.10$ & \\
\hline & 62.50 & $701.17 \pm 4.78$ & $621.11 \pm 2.42$ & & $621.11 \pm 2.42$ & \\
\hline & 15.13 & $714.32 \pm 0.00$ & $667.69 \pm 0.65$ & & $651.79 \pm 0.00$ & \\
\hline & 0 & $736.56 \pm 0.36$ & $736.56 \pm 0.36$ & & $736.56 \pm 0.36$ & \\
\hline Patient with stable & 250 & $634.82 \pm 27.82$ & $615.57 \pm 0.60$ & 0.128 & $631.69 \pm 4.00$ & 0.106 \\
\hline \multirow[t]{5}{*}{ SLE } & 62.50 & $696.42 \pm 29.50$ & $683.75 \pm 0.99$ & & $691.81 \pm 0.34$ & \\
\hline & 15.13 & $785.72 \pm 11.86$ & $697.55 \pm 1.70$ & & $743.95 \pm 0.73$ & \\
\hline & 3.91 & $808.64 \pm 8.67$ & $727.48 \pm 1.77$ & & $768.96 \pm 2.99$ & \\
\hline & 0 & $816.18 \pm 4.37$ & $816.18 \pm 4.37$ & & $816.18 \pm 4.37$ & \\
\hline & & & & 0.323 & & 0.718 \\
\hline Patient with active & 250 & $928.69 \pm 0.91$ & $673.01 \pm 0.63$ & & $667.01 \pm 0.33$ & \\
\hline \multirow[t]{5}{*}{ SLE } & 62.50 & $926.14 \pm 0.90$ & $667.01 \pm 0.33$ & & $692.52 \pm 1.35$ & \\
\hline & 15.12 & $910.01 \pm 1.33$ & $673.01 \pm 2.29$ & & $707.71 \pm 0.35$ & \\
\hline & 3.91 & $909.07 \pm 1.77$ & $704.55 \pm 2.06$ & & $747.81 \pm 3.28$ & \\
\hline & 0 & $890.48 \pm 2.60$ & $890.48 \pm 2.60$ & & $890.48 \pm 2.60$ & \\
\hline & & & & 0.002 & & 0.003 \\
\hline
\end{tabular}

p value was adjusted based on the concentration of Ig G in cultured lymphocytes with the extract treatment 
In the statistical results indicated that a decrease in the concentration of Ig G from healthy volunteer, patient with stable SLE, and in patients with active SLE. In Table 2 also showed that the decrease in the concentration of immunoglobulin $\mathrm{G}$ occurred significantly from lowest to highest concentration of aspirin. This suggested that suppression of immunoglobulin $G$ concentrations in lymphocytes cultured cells through inhibition of the enzymecyclooxigenase.

Effect ofcyclooxygenase 2 (COX-2) inhibitor of the extract on B cell function, assessed as Ig $\mathrm{G}$ autoantibody production. Based on our studies on lupus lymphocytes in vitro from humans, we designed the present study to test the effects of suppression $\operatorname{Ig} \mathrm{G}$ secretion by aspirin as cyclooxygenase inhibitor and prednisone as immunosuppressive agent. Surprisingly, the low dose and high dose of aspirin and prednisone were effective in suppressing secretion of $\mathrm{Ig} G$ from lymphocytes of patient with active SLE, stable SLE, and healthy volunteer. Prednisone was the most potent in suppressing Ig G (15). Moreover, therapy with the COX-2 inhibitors, aspirin, in the short term, even at the lowest doses, could also suppress the functions of B cells reducing Ig $\mathrm{G}$ auto antibody production in response to the major lupus auto antigen, nucleosome (16)(17).

Baseline levels of Ig $G$ autoantibodies produced by lymphocytes culture, were as follows: for either healthy volunteer or patient with stable SLE in the concentration of the extract above 62.5 $\mu \mathrm{g} / \mathrm{mL}$ were significance decrease but not for patient with active SLE, it was significance increase between the lowest dose and the highest dose. Lymphocytes from active SLE actually hyper expressed
COX-2 for B cells activation which could have been inhibited by prednisone and aspirin. The hyperactive B cells of lupus not only produce Ig $\mathrm{G}$ auto antibodies, but also co stimulate and present auto antigens to pathogenic $\mathrm{T}$ cells in lymphocytes cells line, and may stimulate themselves by increasing activity of COX-2 (18). In relation to human lupus, this study shows the importance of COX-2 as a target for stable lupus therapy, using aspirin, prednisone, and the extract of Tridax procumbens. It would be interesting to explore whether Tridax procumbens has difference pathway to suppress autoantibody in active SLE. Eventhough, based on this study, the extract ofethyl acetate from Tridax procumbens is not recommended for patients with active SLE. This can be caused by an autoimmune nature of B lymphocyte cells are hyperactive but this phenomenon requires further research.

\section{CONCLUSIONS}

The extract of Tridax procumbens had immunosuppressive effects in reducing the concentration of immunoglobulin $\mathrm{G}$ significantly in cultured lymphocytes of SLE patients with stable and healthy individual with concentrations of the extract above $62.5 \mu \mathrm{g} / \mathrm{mL}$.

The extract of Tridax procumbens increased the concentration of immunoglobulin G inactive SLE patients in vitro.

\section{RECOMMENDATIONS}

The extract of Tridax procumbens needs to explore in-depth to suppress secretion of immunoglobulin $G$ in either difference 
Immunosupressant Effect of the Extract of Tridax Procumbens on Lymphocyte Cells Line from Patients with Systemic Lupus Erythematous: Immunoglobulin Gbiomarker

autoimmune diseases or difference pathway trasduction.

This study needs further research to determine the components contained in the ethyl acetate extract Tridax procumbens.

\section{ACKNOWLEDGEMENT}

The authors thank to Yayasan Syamsi Dhuha Foundation as funding for this study; volunteers who followed the protocol of the study; Miss Tri Yuliasih as laboratory technician at laboratory for research and analyzing, University of Gadjah Mada; and Mrs Nanik and Mr Heru as ners helped to select the patients with lupus at Department of Rheumatology, Internal Medicine, Hospital of DR. Sardjito.

\section{REFERENCES}

1. Renau AI ID. Male versus female lupus: a comparison of ethnicity, clinical features, serology and outcome over a 30 year period. Lupus. 2012;21(10):1041-8.

2. Radic M, Martinovic Kaliterna D RJ. Vascular manifestations of systemic lupus erythematosis. Neth J Med. 2013;71(1):10-6.

3. Erythematosus L. Diagnosis of Systemic Lupus Erythematosus. American Family Physician. 2003;68(11):2179-86.

4. Djoerban Z. Pengobatan Penyakit Lupus Eritematosus Sistemik. Sub Bagian Hematologi, Bagian Ilmu Penyakit Dalam FKUI-RSCM. Jakarta; 2002.

5. Mok CC LC. Pathogenesis of systemic lupus erythematosus. J Clin Pathol. 2003;56(7):481-90.

6. Jachak SM, Gautam R, Selvam C, Madhan H, Srivastava A KT. Antiinflammatory,

cyclooxygenase inhibitory and antioxidant activities of standardized extracts of Tridax procumbens $L$. $\quad$ Fitoterapia. 2011;82(2):173-7.

7. Ismawan B. Herbal Indonesia Berkhasiat. Vol 08. Depok: PT Trubus Swadaya; 2010. p. 446-7.

8. Taddei A R-RA. Bioactivity studies of extracts from Tridax procumbens. Phytomedicine. 2000;7(3):235-8.

9. Yaduvanshi B, Mathur R, Mathur SR VT. Evaluation of wound healing potential of topical formulation of leaf juice of tridax procumbens L. In mice. Indian J Pharm Sci. 2011;73(3):303-6.

10. Diwan PV, Tilloo LD KD. Steroid depressed wound healing and Tridax procumbens. Indian J Physiol Pharmacol. 1983;27(1):32-6.

11. Ryan EP, Pollock SJ, Pollack SJ, Murant TI, Bernstein SH, Felgar RE, et al. Activated human $B$ lymphocytes express cyclooxygenase-2 and cyclooxygenase inhibitors attenuate antibody production. Journal of immunology. 2005 Mar 1;174(5):261926.

12. Press D. B-cell targeted therapy in systemic lupus erythematosus: potential of rituximab. 2012;347-54.

13. Rantam FA. Metode Imunologi. Surabaya: Airlangga University Pers; 2003.

14. Bastian BC, Römisch J, Pâques EP BG. Lipocortins and phospholipases: new aspects in the physiology of glucocorticosteroid effect. Hautarzt. 1991;42(7):417-23.

15. Losy J, Michałowska-Wender G WM. The effect of large-dose prednisone therapy on $\operatorname{Ig} G$ subclasses in multiple sclerosis. Acta Neurol Scand. 1994;89(1):69-71.

16. Smith HS. Aspirin-inspired analgesia: old drug, new mechanism, Sans Cox? Pain physician. 2012;15(4):E359-61. 
Immunosupressant Effect of the Extract of Tridax Procumbens on Lymphocyte Cells Line from Patients with Systemic Lupus Erythematous: Immunoglobulin Gbiomarker

17. Malaviya AN MM. Should low-dose aspirin also be a background therapy for all patients with systemic lupus erythematosus (SLE)? Lupus. 2000;9(7):561-2.
18. Caza TN, Talaber G PA. Metabolic regulation of organelle homeostasis in lupus $T$ cells. Clin Immunol. 2012;144(3):200-13. 